\title{
Article \\ Compost-Based Growing Media Improved Yield of Leafy Lettuce in Pot Culture
}

\author{
Mari Marutani ${ }^{1, *}$ and Seanne Clemente ${ }^{2}$ \\ 1 Agriculture and Life Science Division, College of Natural and Applied Sciences, University of Guam, \\ Mangilao, GU 96910, USA \\ 2 Department of Biology, University of Massachusetts Amherst, Amherst, MA 01003, USA; \\ srclemente@umass.edu \\ * Correspondence: marutanim@triton.uog.edu
}

Citation: Marutani, M.; Clemente, S. Compost-Based Growing Media Improved Yield of Leafy Lettuce in Pot Culture. Agronomy 2021, 11, 1762. https://doi.org/10.3390/

agronomy11091762

\section{Academic Editors:}

Theodore Radovich, Michael Kantar and Robert E Paull

Received: 11 August 2021

Accepted: 30 August 2021

Published: 1 September 2021

Publisher's Note: MDPI stays neutral with regard to jurisdictional claims in published maps and institutional affiliations.

Copyright: (c) 2021 by the authors. Licensee MDPI, Basel, Switzerland. This article is an open access article distributed under the terms and conditions of the Creative Commons Attribution (CC BY) license (https:// creativecommons.org/licenses/by/ $4.0 /)$.

\begin{abstract}
Compost-based media were examined for effects on plant growth of leafy lettuce (Lactuca sativa L.) in pot culture. Four types of locally sourced composts were created using different proportions of wood chips from untreated pallets and mixed tropical tree debris, food waste from restaurants, and chicken manure. Compost-based media were prepared by mixing each compost with a commercial peatmoss to create 25,50 , and $100 \%$ compost-peatmoss mixtures (by volume). In Trial One, cv. Starfighter had the greatest shoot (leaves/stems) biomass when grown in 100\% compost containing wood chips, food waste, and chicken manure. In Trial Two, cvs. Starfighter and New Red Fire were examined. Growing media affected all plant growth parameters including fresh and dry shoots and roots, shoot and root length, and number of leaves. Cultivar affected all except fresh root weight. Interaction effects of growing medium and cultivar type were found for fresh shoot weight, dry root weight, shoot, and root length. Regression analyses indicated increases in amount of compost in growing media increased dry shoot and root weights. Composts containing recyclable organic materials can be an alternative to commercial media in pot culture.
\end{abstract}

Keywords: Lactuca sativa; food waste compost; recyclable organic materials

\section{Introduction}

Commercial growing media used for container production primarily consists of peatmoss with sand, Perlite, or vermiculite. Continuing use of peat-based media may not be sustainable because of shortage of supply due to relatively slow recovery of peat bogs after harvest and bogs being valuable as sanctuaries in natural habitats [1]. Composts are used as amendments to soil and commercial peat-based media in container culture of vegetables [2-7] including lettuce (Lactuca sativa L.). Lettuce grown in food waste-based composts obtained higher yields and had increased antioxidant activity [8] and soil microbial activity [3] compared to those grown in commercial peatmoss mix. Applying composts in pot culture would promote utilization of waste materials as well as recycling locally available resources.

The objective of the study was to assess compost-based growing media utilizing food waste from local restaurants and wood chips from used pallets and tree debris as potential substitutes for commercial potting mix to grow leafy lettuce.

\section{Materials and Methods}

\subsection{Making Compost}

Four compost windrows $(11 \times 3 \mathrm{M})$ were initially made with woodchips $(\mathrm{W})$ obtained locally from discarded untreated pallets and tree debris on 27 January 2016. Four different types of compost were then created by addition of different amounts of food waste $(F)$ collected from local restaurants and chicken manure $(C)$ that was collected from chicken coops at the University of Guam Agricultural Experiment Station, Yigo Farm, and 
commercial chicken manure sold locally at garden shops. Compost WFC included food waste $(2225 \mathrm{~kg})$ and chicken manure $(612 \mathrm{~kg})$ added to woodchips (17 t). For Compost WF, food waste $(2485 \mathrm{~kg}$ ) was added to woodchips (21 t), while Compost WC was composed of chicken manure $(1771 \mathrm{~kg}$ ) and woodchips $(22 \mathrm{t})$. Compost $\mathrm{W}$ had only wood chips $(20 \mathrm{t})$. For compost containing food waste, the fresh food waste collected from three local restaurants was added gradually pending availability of food waste sources for six months. Composting was completed in three months. Windrows were covered with tarpaulins to protect compost from tropical rainfall for nine months (27 January to 6 October 2016), except when aerated with a windrow turner (Aeromaster PT-120, Midwest Bio-Systems Inc., Tampico, IL, USA) biweekly. The proportions of raw materials that were added into compost mixes by percent of weight were: compost WFC with wood chips $(86 \%)$, food waste $(11 \%)$, and chicken manure (3\%); compost WF with wood chips $(89 \%)$ and food waste (11\%); compost WC with wood chips $(92.5 \%)$ and chicken manure $(7.5 \%)$; and compost W with only wood chips $(100 \%)$.

Chemical characteristics of the four final compost products were analyzed at the Soil Analysis Laboratory, University of Guam, for $\mathrm{pH}$, organic matter $(\mathrm{OM})$ contents of $\mathrm{P}, \mathrm{K}$, $\mathrm{Ca}$ and $\mathrm{Mg}$, and $\mathrm{C} / \mathrm{N}$ ratio of six samples obtained from the north, northwest, northeast, south, southeast, and southwest sides of each windrow. Organic matter was measured according to the Walkley and Black method [9]. The P content was extracted with sodium bicarbonate [10] and determined by colorimeter analysis (Spectronic 21, Bausch and Lomb, Thermo Fisher Scientific Inc. Waltham, MA, USA). Contents of $\mathrm{K}, \mathrm{Ca}$, and Mg were determined using an atomic absorption flame spectrometer (SpectrAA 220 FS, Varian Inc., Palo Alto, CA, USA) [11]. Flash dynamic combustion was used to estimate the C:N ratio (FlashEA 112 Series, Thermo Fischer Scientific Inc., Waltham, MA, USA) [12].

\subsection{Preparation of Growing Media in Pot Culture}

For preparation of 13 growing mix treatments, eight media treatments were prepared by incorporating either 25 or $50 \%$ (by volume) of each compost to commercial peatmoss mix (PM) (Sunshine Mix \#4, Sun Gro Horticulture, Agwam, MA, USA), and were labeled as: WFC25 (WFC /PM $=25 \% / 75 \%)$; WFC50 (WFC $/ \mathrm{PM}=50 \% / 50 \%)$; WF25 $(\mathrm{WF} / \mathrm{PM}=25 \% / 75 \%) ; \mathrm{WF} 50(\mathrm{WF} / \mathrm{PM}=50 \% / 50 \%) ; \mathrm{WC} 25(\mathrm{WC} / \mathrm{PM}=25 \% / 75 \%) ; \mathrm{WC} 50$ $(\mathrm{WC} / \mathrm{PM}=50 \% / 50 \%) ; \mathrm{W} 25(\mathrm{~W} / \mathrm{PM}=25 \% / 75 \%) ;$ or W50 (W/PM $=50 \% / 50 \%)$. The $100 \%$ of each compost medium were designated: WFC100, WF100, WC100 or W100. Additionally, $100 \%$ commercial peatmoss mix (PM) was included as control. Table 1 lists the designated names of 13 growing media examined in the pot culture study, indicating the proportions (\%) of compost and commercial peatmoss mix incorporated to compost.

Table 1. Proportion of compost and commercial peatmoss mix for growing media.

\begin{tabular}{cccc}
\hline Growing Medium & Compost Type ${ }^{\mathbf{a}}$ & Compost $(\%$ by Volume) & Peatmoss Mix (PM $\left.^{\mathbf{b}}\right)(\% \mathbf{b y}$ Volume) \\
\hline WFC25 & WFC & 25 & 75 \\
WFC50 & WFC & 50 & 50 \\
WFC100 & WFC & 100 & 0 \\
WF25 & WF & 25 & 75 \\
WF50 & WF & 50 & 50 \\
WF100 & WF & 100 & 75 \\
WC25 & WC & 25 & 50 \\
WC50 & WC & 50 & 0 \\
WC100 & W & 100 & 75 \\
W25 & W & 25 & 50 \\
W50 & W & 100 & 0 \\
W100 & & 0 & 100 \\
PM & & 50 &
\end{tabular}

${ }^{\text {a }}$ Compost WFC = compost of wood chips from untreated pallets and mixed tropical tree debris, food waste, and chicken manure; Compost $\mathrm{WF}=$ compost of wood chips and food waste; Compost WC = compost of wood chips and chicken manure; Compost W = compost of woodchips only; ${ }^{\mathrm{b}} \mathrm{PM}=$ commercial peatmoss mix. 
Chemical characteristics of the 13 media treatments were examined for $\mathrm{pH}, \mathrm{OM}(\%)$, and contents of $\mathrm{P}, \mathrm{K}, \mathrm{Ca}$, and $\mathrm{Mg}$ using the procedure described above at: (1) prior to transplanting leafy lettuce seedlings in Trial One (T1), and (2) after harvest in T1 and prior to Trial Two (T2). After harvest in T1, media with the same treatment were compiled and a sample of each treatment was analyzed. Difference in chemical characteristics of the 13 growing media treatments prior to $\mathrm{T} 1$ and after T1(prior to T2) for $\mathrm{OM}(\%), \mathrm{P}, \mathrm{K}, \mathrm{Mg}$, and Ca were determined using the following formula:

$(\%$ decrease from T1 to T2 $)=[($ measurement in T1 $)-($ measurement in T2) $] /($ measurement in T1 $) \times 100$

Lettuce seed were obtained from a commercial company (Johnny's Selected Seeds, Fairfield, ME). For Trial One, 2-week old seedlings of cv. Starfighter were transplanted individually into a pot $(3.78 \mathrm{~L})$ filled with each growth medium on 29 October 2016. There were seven pots (replications) for each growing medium. Pots were placed randomly on a nursery bench. Plants were watered daily at 10:00 a.m. with an overhead sprinkler system until media were moist. No fertilizer was added to plants during the experiment. Plants were harvested including roots by gently shaking them free from media on 3 December 2016. Roots were washed to remove still attached media and air-dried to determine biomass. Any displaced media were returned to the original pot. Shoot (leaves/stem) length was measured from the root collar to the tip of the tallest leaf, and root length was determined by measuring the longest root of a plant. Numbers of leaves per plant were counted. After recording shoot and root fresh weights of each plant separately, dry weights were determined after placing tissues in an oven (SMO28G-2 Shel Lab Performance Oven, Shel Lab, Cornelius, OR, USA) for $48 \mathrm{~h}$ at $55^{\circ} \mathrm{C}$.

For Trial Two, growing media with the same treatment were aggregated after Trial One and divided into eight pots. On 16 January 2017, 2-week old seedlings of cvs. Starfighter and New Red Fire were transplanted to pots. The growing media and cultivars with four replications (pots) were placed on a bench in a randomized complete block design. Plants were irrigated without supplemental fertilizer application. At harvest on 17 February 2017, plant growth parameters measured included lengths of shoots and roots, numbers of leaves, and fresh and dry weights of shoots and roots with the same procedure used in Trial One.

The data were subjected to analysis of variance to compare chemical characteristics of the final compost products prior to making growing media treatments. Mean comparisons were with Tukey's test if applicable. Difference in chemical analyses of growing media treatments before and after Trial One were compared by determining the average and standard deviation of the "\% decrease" for OM(\%), P, K, Mg, and Ca.

To verify the effects on growth of cv. Starfighter due to media treatment in Trial One, analysis of variance was performed using a completely randomized design with seven replications. For Trial Two, analysis of variance was carried out using a randomized complete block design with the treatment factors, growing media and cultivar type, with four replications to determine plant responses affected by two individual factors and the interaction of two factors. Separation of means was with Tukey's test if applicable.

All analysis of variance and mean separation were conducted with $R$ Version 3.1.0 [13] and the 'lme4' package [14]. Further, for Trial Two possible existence of relationships between dry shoot and dry root weights with amount of compost (\%) were determined by regression analyses for each compost type, WFC, WF, WC, and W, using JMP (ver. 15, SAS Institute Inc., Cary, NC, USA) and Prism (ver. 8, GraphPad Software, San Diego, CA, USA). Simple statistics were performed using Excel ver.16.42 (Microsoft, Redmond, WA, USA).

\section{Results and Discussion}

Chemical analyses of the composts varied (Table 2). The $\mathrm{C} / \mathrm{N}$ ratios of composts ranged from 39 (for Compost WFC and Compost WF) to 54 (for Compost W), which were reduced from the $\mathrm{C} / \mathrm{N}$ ratio of 120 obtained from the original base materials of wood chips at the beginning of composting. The C/N ratios obtained were much higher than 19, the ideal $\mathrm{C} / \mathrm{N}$ ratio for optimal growth previously reported by Kumar et al. [15]. Another 
study that utilized food waste and wood chip-based composts reported $\mathrm{C} / \mathrm{N}$ ratios as low as 12 [16]. Concentrations of $\mathrm{P}, \mathrm{K}$, and $\mathrm{Mg}$ were higher in composts including chicken manure (Table 2). The amount of $\mathrm{P}$ was highest with Compost WC, followed by Compost WFC, WF, and W. The amount of K was greatest with Compost WFC and WC, followed by Compost WF and Compost W. The concentration of Mg was greatest with Compost WC followed by Compost WFC. The lowest Mg concentrations were for Compost WF and W. The high concentration of $\mathrm{Ca}$ of all composts was possibly caused by the unintentional incorporation of lime-rich soil particles from the calcareous soils beneath the compost windrows during aeration via a windrow turner.

Table 2. Percent weights of original materials composted to create Compost WFC, Compost WF, Compost WC, and Compost $\mathrm{W}$, utilizing wood chips from untreated pallets and mixed tropical tree debris $(\mathrm{W})$, food waste $(\mathrm{F})$, and chicken manure $(\mathrm{C})$; and chemical characteristics of final compost products prior to testing their effects on growth of lettuce in pot culture.

\begin{tabular}{|c|c|c|c|c|c|c|c|c|}
\hline \multirow[b]{2}{*}{$\begin{array}{l}\text { Compost } \\
\text { Type }^{\mathrm{a}}\end{array}$} & \multirow[b]{2}{*}{$\begin{array}{c}\text { Composted } \\
\text { Materials (\% } \\
\text { by Weight) }\end{array}$} & \multicolumn{7}{|c|}{ Chemical Characteristics of Final Compost Product } \\
\hline & & $\mathrm{pH}$ & $\begin{array}{c}\text { Organic } \\
\text { Matter (\%) }\end{array}$ & $\mathrm{C} / \mathrm{N}$ & $P\left(\mathbf{m g} \cdot \mathbf{k g}^{-1}\right)$ & $\mathrm{K}\left(\mathrm{mg} \cdot \mathrm{kg}^{-1}\right)$ & $\mathrm{Ca}\left(\mathrm{mg} \cdot \mathrm{kg}^{-1}\right)$ & $\operatorname{Mg}\left(\mathrm{mg} \cdot \mathrm{kg}^{-1}\right)$ \\
\hline WFC & $\begin{array}{c}\mathrm{W} / \mathrm{F} / \mathrm{C} \\
(86 / 11 / 3)\end{array}$ & $6.75 \mathrm{a}^{\mathrm{b}}$ & $9.3 \mathrm{a}$ & $39 \mathrm{~b}$ & $43.4 \mathrm{~b}$ & $165.0 \mathrm{a}$ & $7071 \mathrm{~b}$ & $386 \mathrm{~b}$ \\
\hline WF & $\mathrm{W} / \mathrm{F}(89 / 11)$ & $6.73 \mathrm{a}$ & $8.1 \mathrm{ab}$ & $39 \mathrm{~b}$ & $22.9 \mathrm{c}$ & $94.2 \mathrm{~b}$ & $7305 \mathrm{~b}$ & $178 \mathrm{c}$ \\
\hline WC & $\begin{array}{c}\mathrm{W} / \mathrm{C} \\
(92.5 / 7.5)\end{array}$ & $6.51 \mathrm{~b}$ & $8.2 \mathrm{ab}$ & $47 \mathrm{ab}$ & $60.9 \mathrm{a}$ & $157.2 \mathrm{a}$ & $6758 \mathrm{~b}$ & 472 a \\
\hline W & W (100) & $6.57 \mathrm{ab}$ & $7.7 \mathrm{~b}$ & $54 \mathrm{a}$ & $11.1 \mathrm{~d}$ & $28.7 \mathrm{c}$ & 8737 a & $156 \mathrm{c}$ \\
\hline
\end{tabular}

${ }^{a}$ Compost WFC = compost of wood chips, food waste, and chicken manure; Compost WF = compost of wood chips and food waste; Compost WC = compost of wood chips and chicken manure; Compost $\mathrm{W}=$ compost of woodchips only. ${ }^{\mathrm{b}}$ Mean values followed by the same letter in a column are not significantly different, $p<0.05$, Tukey's test $(n=6)$; six samples for each compost were taken from the north, northwest, northeast, south, southeast, and southwest sides of each windrow (compost pile).

Table 3. Chemical characteristics of growing medium for lettuce production prior to Trial One (T1) and Trial Two (T2) and decrease $(\%)$ from $\mathrm{T} 1$ to $\mathrm{T} 2$.

\begin{tabular}{|c|c|c|c|c|c|c|c|c|c|c|c|c|c|c|c|c|c|}
\hline \multirow{2}{*}{$\begin{array}{l}\text { Growing } \\
\text { Medium }^{\text {a }}\end{array}$} & \multicolumn{2}{|c|}{$\mathrm{pH}$} & \multicolumn{3}{|c|}{ OM (\%) } & \multicolumn{3}{|c|}{$P\left(\mathrm{mg} \cdot \mathrm{kg}^{-1}\right)$} & \multicolumn{3}{|c|}{$\mathrm{K}\left(\mathrm{mg} \cdot \mathrm{kg}^{-1}\right)$} & \multicolumn{3}{|c|}{$\mathrm{Mg}\left(\mathrm{mg} \cdot \mathrm{kg}^{-1}\right)$} & \multicolumn{3}{|c|}{$\mathrm{Ca}\left(\mathrm{g} \cdot \mathrm{kg}^{-1}\right)$} \\
\hline & T1 & $\mathrm{T} 2$ & T1 & T2 & $\%$ & T1 & $\mathrm{T} 2$ & $\%$ & $\mathrm{~T} 1$ & $\mathrm{~T} 2$ & $\%$ & T1 & $\mathrm{T} 2$ & $\%$ & T1 & $\mathrm{T} 2$ & $\%$ \\
\hline WFC25 & $6.6^{b}$ & 7 & 28.4 & 19.2 & 32 & 42.4 & 34.1 & 20 & 673 & 69 & 90 & 1377 & 1157 & 16 & 21.8 & 12.9 & 41 \\
\hline WFC50 & 6.7 & 6.9 & 27.8 & 11.7 & 58 & 41.7 & 32.5 & 22 & 436 & 57 & 87 & 859 & 727 & 15 & 14 & 8.9 & 36 \\
\hline WFC100 & 6.7 & 7.1 & 11.3 & 10 & 12 & 43.7 & 31.2 & 29 & 191 & 40 & 79 & 464 & 463 & 0 & 9.8 & 7.6 & 22 \\
\hline WF25 & 6.6 & 6.8 & 24.3 & 17.6 & 28 & 30.5 & 30.1 & 1 & 603 & 56 & 91 & 1111 & 827 & 26 & 14 & 11.6 & 17 \\
\hline WF50 & 7 & 6.7 & 15.2 & 10.8 & 29 & 29.8 & 24.2 & 19 & 318 & 47 & 85 & 640 & 604 & 6 & 11.2 & 8.4 & 25 \\
\hline WF100 & 7.1 & 6.8 & 9.2 & 7.1 & 23 & 25 & 14.5 & 42 & 73 & 27 & 63 & 167 & 274 & $(-64)$ & 8.9 & 6.7 & 25 \\
\hline WC25 & 6.5 & 6.7 & 23.3 & 18.2 & 22 & 48.4 & 46.1 & 5 & 551 & 78 & 86 & 1167 & 988 & 15 & 14.5 & 11.1 & 23 \\
\hline WC50 & 6.8 & 6.8 & 18.3 & 10.4 & 43 & 60.6 & 49.1 & 19 & 248 & 80 & 68 & 834 & 673 & 19 & 10.6 & 8.1 & 24 \\
\hline WC100 & 7.1 & 7.2 & 9.4 & 8.5 & 10 & 54.7 & 55.1 & $(-1)$ & 180 & 39 & 78 & 505 & 517 & $(-2)$ & 7.3 & 7.4 & $(-1)$ \\
\hline W25 & 6.9 & 6.8 & 24.3 & 22.5 & 7 & 28 & 30.7 & $(-10)$ & 538 & 78 & 86 & 1047 & 1244 & $(-19)$ & 12.4 & 12.7 & $(-2)$ \\
\hline W50 & 7 & 6.8 & 17.7 & 14.6 & 18 & 22.8 & 22.8 & 0 & 272 & 52 & 81 & 651 & 681 & $(-5)$ & 10.8 & 8.3 & 23 \\
\hline W100 & 7.5 & 6.9 & 10.4 & 7.6 & 27 & 16.8 & 7.7 & 54 & 55 & 29 & 47 & 316 & 169 & 47 & 7.9 & 7.6 & 4 \\
\hline PM & 6.1 & 6.9 & 26.4 & 30.2 & $(-14)$ & 60.2 & 17 & 72 & 1076 & 122 & 89 & 2170 & 2315 & $(-7)$ & 16.6 & 16.5 & 1 \\
\hline \multicolumn{5}{|c|}{ Ave. of $\%$ decrease from $\mathrm{T} 1$ to $\mathrm{T} 2^{\mathrm{c}}$ : } & 22.6 & & & 20.9 & & & 79.1 & & & 3.6 & & & 18.3 \\
\hline \multicolumn{5}{|c|}{ Sd. of $\%$ decrease from $\mathrm{T} 1$ to $\mathrm{T} 2{ }^{\mathrm{c}}$ : } & 17.72 & & & 23.61 & & & 12.68 & & & 26.31 & & & 14.02 \\
\hline
\end{tabular}

${ }^{a}$ Growing medium: WFC25 $=25 \%$ Compost WFC $+75 \%$ PM (by volume); WFC50 $=50 \%$ Compost WFC $+50 \%$ PM; WFC $100=100 \%$ Compost WFC; WF25 = 25\% Compost WF + 75\%PM; WF50 = 50\% Compost WF $+50 \%$ PM; WF100 = 100 $\%$ Compost WF; WC25 = 25\% Compost WC $+75 \% \mathrm{PM} ; \mathrm{WC} 50=50 \%$ Compost WC $+50 \% \mathrm{PM} ; \mathrm{WC} 100=100 \%$ Compost WC; $\mathrm{W} 25=25 \%$ Compost $\mathrm{W}+75 \% \mathrm{PM} ; \mathrm{W} 50=50 \%$ Compost $\mathrm{W}+50 \% \mathrm{PM} ; \mathrm{W} 100=100 \%$ Compost $\mathrm{W}$; and PM $=$ commercial peatmoss mix. Compost WFC was created by utilizing wood chips from untreated pallets and mixed tropical tree debris, food waste, and chicken manure; Compost WF contained wood chips and food waste; Compost WC used wood chips and chicken manure; and Compost $\mathrm{W}$ had woodchips only. ${ }^{\mathrm{b}}$ Values are means of three readings for each growing medium, only mean values were obtained from the Soil Laboratory. ${ }^{\mathrm{c}}$ The $\%$ decrease from $\mathrm{T} 1$ to $\mathrm{T} 2$ calculated with the equation: \% decrease $=[($ measurement in T1 $)-($ measurement in T2) $] /($ measurement in T1 $) \times 100$. The average and standard deviation of $\%$ decrease of all chemical characters except $\mathrm{pH}$ were calculated from \% decrease in 13 growing media from T1 to T2 $(n=13)$. 
The chemical analysis of the growing media prior to Trial One (T1) and Trial Two (T2) varied (Table 3). A conclusive finding in differences in chemical characteristics among the growing media was not available since only a single measurement for each character was obtained. Between T1 and T2, a large K reduction occurred ( $\mathrm{sd}=12.7, n=13)$, indicating $\mathrm{K}$ uptake occurred in plants during T1. The concentration of $\mathrm{K}$ in plant dry mass of lettuce was increased as K supply increased [17]. A high amount of $\mathrm{K}$ was not needed for maximum plant growth [18]. The large absorption of K in T1 might indicate "luxury consumption" where plants absorb and accumulate $\mathrm{K}$ far in excess of their needs [19].

In Trial 1, all growth parameters of cv. Starfighter were influenced by growing media. Growth parameters were affected by growing media treatments (Table 4). Plants grown in WFC100 (100\% Compost WFC) exhibited the most vigorous growth followed by WF100 compost, while plants grown in the control (PM) had the least. Shoot length and number of leaves per plant were greatest when plants were grown in WFC100. Growing media with $100 \%$ woodchips compost (W100) produced the least dry shoot and root mass (Table 4).

Table 4. Effects of growing media on shoot and root growth and number of leaves of lettuce (Lactuca sativa) cv. Starfighter in Trial 1.

\begin{tabular}{|c|c|c|c|c|c|c|c|}
\hline \multirow{2}{*}{ Growing Medium a } & \multicolumn{2}{|c|}{ Shoot Weight } & \multicolumn{2}{|c|}{ Root Weight } & \multirow{2}{*}{$\begin{array}{c}\text { Shoot } \\
\text { Length }(\mathrm{cm})\end{array}$} & \multirow{2}{*}{$\begin{array}{l}\text { Root Length } \\
\text { (cm) }\end{array}$} & \multirow{2}{*}{ No. of Leaves } \\
\hline & Fresh $(g)$ & Dry (g) & Fresh (g) & Dry (g) & & & \\
\hline WFC25 & $7.6 \mathrm{~d}^{\mathrm{b}}$ & 0.67 ef & $2.57 \mathrm{bc}$ & $0.40 \mathrm{de}$ & $7.8 \mathrm{f}$ & $23.3 \mathrm{ab}$ & $10.9 \mathrm{e}$ \\
\hline WFC50 & $21.4 \mathrm{~cd}$ & $1.85 \mathrm{c}-\mathrm{f}$ & $3.71 \mathrm{bc}$ & $0.45 \mathrm{c}-\mathrm{e}$ & $12.5 \mathrm{~cd}$ & $22.1 \mathrm{ab}$ & $16.4 \mathrm{bc}$ \\
\hline WFC100 & $58.0 \mathrm{a}$ & $7.35 \mathrm{a}$ & $6.57 \mathrm{a}$ & $0.82 \mathrm{ab}$ & $17.8 \mathrm{a}$ & $18.4 \mathrm{~b}$ & $20.3 \mathrm{a}$ \\
\hline WF25 & $16.0 \mathrm{~d}$ & $1.49 \mathrm{~d}-\mathrm{f}$ & $4.17 \mathrm{a}-\mathrm{c}$ & $0.64 \mathrm{a}-\mathrm{e}$ & $11.2 \mathrm{c}-\mathrm{e}$ & $25.1 \mathrm{ab}$ & $14.3 \mathrm{c}-\mathrm{e}$ \\
\hline WF50 & $13.1 \mathrm{~d}$ & $1.23 \mathrm{~d}-\mathrm{f}$ & $3.57 \mathrm{bc}$ & $0.48 \mathrm{~b}-\mathrm{e}$ & $11.2 \mathrm{c}-\mathrm{e}$ & $23.4 \mathrm{ab}$ & $13.3 \mathrm{c}-\mathrm{e}$ \\
\hline WF100 & $39.6 \mathrm{~b}$ & $4.51 \mathrm{~b}$ & $5.14 \mathrm{ab}$ & $0.62 \mathrm{~b}-\mathrm{e}$ & $15.5 \mathrm{ab}$ & $20.9 \mathrm{ab}$ & $19.4 \mathrm{ab}$ \\
\hline WC25 & $16.7 \mathrm{~cd}$ & $2.01 \mathrm{c}-\mathrm{e}$ & $4.57 \mathrm{a}-\mathrm{c}$ & $0.98 \mathrm{a}$ & $11.3 \mathrm{c}-\mathrm{e}$ & $27.4 \mathrm{a}$ & $14.9 \mathrm{~cd}$ \\
\hline WC50 & $18.6 \mathrm{~cd}$ & $2.23 \mathrm{~cd}$ & $4.57 \mathrm{a}-\mathrm{c}$ & $0.84 \mathrm{ab}$ & $12.5 \mathrm{c}$ & $22.4 \mathrm{ab}$ & $16.3 \mathrm{bc}$ \\
\hline WC100 & $26.7 c$ & $3.00 \mathrm{c}$ & $6.57 \mathrm{a}$ & $1.00 \mathrm{a}$ & $13.8 \mathrm{bc}$ & $21.6 \mathrm{ab}$ & $17.0 \mathrm{a}-\mathrm{c}$ \\
\hline W25 & $15.6 \mathrm{~d}$ & $1.49 \mathrm{~d}-\mathrm{f}$ & $4.00 \mathrm{a}-\mathrm{c}$ & $0.66 \mathrm{a}-\mathrm{d}$ & $10.9 c-e$ & $22.4 \mathrm{ab}$ & 11.9 de \\
\hline W50 & $8.3 \mathrm{~d}$ & 0.88 ef & $2.71 \mathrm{bc}$ & $0.50 \mathrm{~b}-\mathrm{e}$ & $9.8 \mathrm{~d}-\mathrm{f}$ & $22.3 \mathrm{ab}$ & 11.9 de \\
\hline W100 & $8.1 \mathrm{~d}$ & $0.64 \mathrm{f}$ & $2.43 c$ & $0.29 \mathrm{e}$ & 9.3 ef & $20.7 \mathrm{ab}$ & $12.9 \mathrm{de}$ \\
\hline PM (control) & $13.8 \mathrm{~d}$ & $1.60 \mathrm{c}-\mathrm{f}$ & $4.67 \mathrm{a}-\mathrm{c}$ & $0.80 \mathrm{a}-\mathrm{c}$ & $11.2 \mathrm{c}-\mathrm{e}$ & $18.3 \mathrm{~b}$ & $14.3 \mathrm{c}-\mathrm{e}$ \\
\hline
\end{tabular}

${ }^{\mathrm{a}}$ Growing medium: WFC25 $=25 \%$ Compost WFC $+75 \% \mathrm{PM}$ (by volume); WFC50 $=50 \%$ Compost WFC $+50 \% \mathrm{PM}$; WFC $100=100 \%$ Compost WFC; WF25 = 25\% Compost WF + 75\%PM; WF50 = 50\% Compost WF + 50\%PM; WF100 = 100 $\%$ Compost WF; WC $25=25 \%$ Compost WC $+75 \% \mathrm{PM} ; \mathrm{WC} 50=50 \%$ Compost WC $+50 \% \mathrm{PM} ; \mathrm{WC} 100=100 \%$ Compost WC; W25 $=25 \%$ Compost W $+75 \% \mathrm{PM} ; \mathrm{W} 50=50 \%$ Compost $\mathrm{W}+50 \% \mathrm{PM} ; \mathrm{W} 100=100 \%$ Compost $\mathrm{W}$; and PM= commercial peatmoss mix. Compost WFC was created by utilizing wood chips from untreated pallets and mixed tropical tree debris, food waste, and chicken manure; Compost WF contained wood chips and food waste; Compost WC used wood chips and chicken manure; and Compost W had woodchips only. ${ }^{\mathrm{b}}$ values followed by the same letter in a column are not significantly different, $p<0.05$, Tukey's test $(n=7)$.

For Trial Two, results of analysis of variance varied (Table 5). Growing media affected all plant growth parameters, and cultivar type influenced all parameters except fresh root weight. There were interaction effects of growing media and cultivars on fresh shoot weight, dry root weight, and shoot length, and root length.

Table 5. Analysis of variance for plant response as affected by growing medium and cultivar in Trial 2.

\begin{tabular}{|c|c|c|c|c|c|c|c|}
\hline \multirow{2}{*}{ Source } & \multicolumn{2}{|c|}{ Shoot Weight } & \multicolumn{2}{|c|}{ Root Weight } & \multirow{2}{*}{$\begin{array}{c}\text { Shoot } \\
\text { Length (cm) }\end{array}$} & \multirow{2}{*}{$\begin{array}{l}\text { Root Length } \\
\text { (cm) }\end{array}$} & \multirow{2}{*}{ No. of Leaves } \\
\hline & Fresh (g) & Dry(g) & Fresh (g) & Dry (g) & & & \\
\hline $\begin{array}{c}\text { Growing } \\
\text { medium }(\mathrm{G})\end{array}$ & $* * * a$ & * & $* * *$ & $* * *$ & $* * *$ & $* *$ & $* * *$ \\
\hline Cultivar (C) & $* * *$ & $* * *$ & ns & $* * *$ & $* * *$ & $* * *$ & * \\
\hline $\mathrm{G} \times \mathrm{C}$ & $*$ & ns & ns & $*$ & $*$ & $* *$ & ns \\
\hline
\end{tabular}

\footnotetext{
$\mathrm{a}, * * * * * * *, \mathrm{~ns} ; p \leq 0.05, p \leq 0.01, p \leq 0.001$, nonsignificant, respectively.
} 
The effects of growing media in Trial Two on dry shoot weight, fresh root weight, and number of leaves per plant varied (Table 6). Compared to plants grown in control media (PM), dry shoot weight was greater when lettuce was cultivated in the media in the following order: WFC50 > WFC100 $>$ WF100 $>$ WC50 > WC100. Fresh root weight was greater for plants grown in the media in the following order: WFC25 $>$ WFC50 $>$ WFC100 $>$ WF100 > WC100 compared to the control. The number of leaves per plant was higher for lettuce grown in the media in the following order: WFC25 > WFC50 > WFC100 > WF50 > WF100 $>$ WC50 $>$ WC100 > control. According to the ANOVA, cv. New Red Fire produced higher dry shoot weight than did cv. Starfighter, and cv. Starfighter produced more leaves than cv. New Red Fire.

Table 6. Effects of growing medium on dry shoot weight and the number of leaves of lettuce in Trial 2.

\begin{tabular}{|c|c|c|c|}
\hline Growing Medium $^{a}$ & Dry Shoot Weight (g) & Fresh Root Weight (g) & No. Leaves \\
\hline WFC25 & $1.19 \mathrm{~b}-\mathrm{d}^{\mathrm{b}}$ & $2.88 \mathrm{~b}-\mathrm{d}$ & $13.4 \mathrm{~b}-\mathrm{d}$ \\
\hline WFC50 & $1.79 \mathrm{ab}$ & $3.50 \mathrm{~b}$ & $14.6 \mathrm{a}-\mathrm{c}$ \\
\hline WFC100 & $2.43 \mathrm{a}$ & $5.50 \mathrm{a}$ & $17.4 \mathrm{a}$ \\
\hline WF25 & $0.83 \mathrm{~b}-\mathrm{d}$ & $2.63 \mathrm{~b}-\mathrm{e}$ & $10.9 \mathrm{~d}-\mathrm{f}$ \\
\hline WF50 & $1.14 \mathrm{~b}-\mathrm{d}$ & $2.63 \mathrm{~b}-\mathrm{e}$ & $12.3 \mathrm{c}-\mathrm{e}$ \\
\hline WF100 & $1.48 \mathrm{a}-\mathrm{c}$ & $3.04 \mathrm{bc}$ & $13.5 \mathrm{~b}-\mathrm{d}$ \\
\hline WC25 & $0.56 \mathrm{~cd}$ & $1.13 \mathrm{de}$ & $10.9 \mathrm{~d}-\mathrm{f}$ \\
\hline WC50 & $1.36 \mathrm{bc}$ & $1.88 \mathrm{~b}-\mathrm{e}$ & $13.2 \mathrm{~b}-\mathrm{e}$ \\
\hline WC100 & $2.33 \mathrm{a}$ & $3.25 \mathrm{~b}$ & $16.0 \mathrm{ab}$ \\
\hline W25 & $0.56 \mathrm{~cd}$ & $1.67 \mathrm{c}-\mathrm{e}$ & $10.9 \mathrm{~d}-\mathrm{f}$ \\
\hline W50 & $0.77 \mathrm{~b}-\mathrm{d}$ & $1.25 \mathrm{c}-\mathrm{e}$ & $11.2 \mathrm{c}-\mathrm{f}$ \\
\hline W100 & $0.74 \mathrm{~b}-\mathrm{d}$ & $1.13 \mathrm{de}$ & 9.7 ef \\
\hline PM (control) & $0.26 \mathrm{~d}$ & $1.00 \mathrm{e}$ & $7.6 \mathrm{f}$ \\
\hline
\end{tabular}

\footnotetext{
${ }^{a}$ Growing medium: WFC25 = 25\%WFC Compost + 75\%Peatmoss (PM); WFC50 = 50\%WFC Compost + 50\%PM; WFC $100=100 \%$ WFC Compost; WF25 $=25 \%$ WF Compost $+75 \%$ PM; WF50 $=50 \%$ WF Compost $+50 \%$ PM; WF100 $=100 \%$ WF Compost; WC $25=25 \%$ WC Compost + 25\%PM; WC50 = 50\%WC Compost + 50\%PM; WC100 = 100\%WC Compost 100\%; W25 = 25\%W Compost + 75\%PM; W50 = 50\%W Compost $+50 \% \mathrm{PM} ; \mathrm{W} 100=100 \% \mathrm{~W}$ Compost; and $\mathrm{PM}=100 \%$ Peatmoss mix by volume. ${ }^{\mathrm{b}}$ Values followed by the same letter in a column are not significantly different, $p<0.05$, Tukey's test for growing medium.
}

The interaction of growing medium and cultivar on fresh shoot weight, dry root weight, and shoot and root length in Trial Two varied (Table 7). The fresh shoot weight of cv. New Red Fire grown in WFC25, WFC50, WFC100, and WC100 and cv. Starfighter grown in WFC100 was greater than that of both cultivars grown in PM (control). Cv. Starfighter and cv. New Red Fire grown in WFC100, cv. Starfighter grown in WF100, and cv. Starfighter and cv. New Red Fire grown in WC100 had greater dry root weight than either cultivar grown in the control. The shoot length and root length was greatest for $\mathrm{cv}$. New Red Fire grown in WC100.

Regression analysis (Figures 1-4) further presented effects of composts incorporated in growing media in Trial Two. There were linear or quadratic relationships between the proportion of composts (\%) used in media and the plant responses of dry shoot and root weights for each cultivar in Compost WFC, WF, and WC at a significant level, except for a quadratic line fitting the dry root weight of cv. Starfighter in Compost WFC and a linear line fitting the dry root weight of cv. New Red Fire in Compost WF. For Compost W, the regression analyses were not consistent, having a quadratic line fitting the dry shoot weight of cv. Starfighter', both linear and quadratic for the dry shoot weight of cv. New Red Fire, and a linear relation between the dry root weight for cv. New Red Fire. No obvious relationship occurred between the dry root weight of cv. Starfighter and the amount of Compost W. 
Table 7. Interaction effects of growing medium and type of cultivar on dry root weight, shoot and root length of lettuce in Trial 2.

\begin{tabular}{|c|c|c|c|c|c|}
\hline Growing Medium ${ }^{a}$ & Cultivar & $\begin{array}{l}\text { Fresh Shoot } \\
\text { Weight (g) }\end{array}$ & $\begin{array}{c}\text { Dry Root Weight } \\
\text { (g) }\end{array}$ & Shoot Length (cm) & Root Length (cm) \\
\hline \multirow{2}{*}{ WFC25 } & Starfighter & $8.5 \mathrm{f}$ & $0.29 a-c^{b}$ & $7.6 \mathrm{hi}$ & $23.0 \mathrm{ab}$ \\
\hline & New Red Fire & $32.8 \mathrm{a}-\mathrm{d}$ & $0.30 \mathrm{a}-\mathrm{c}$ & $14.9 \mathrm{a}-\mathrm{c}$ & $19.9 \mathrm{a}-\mathrm{c}$ \\
\hline \multirow{2}{*}{ WFC50 } & Starfighter & $21.3 \mathrm{~b}-\mathrm{f}$ & $0.41 \mathrm{a}-\mathrm{c}$ & $12.3 \mathrm{a}-\mathrm{g}$ & $20.4 \mathrm{a}-\mathrm{c}$ \\
\hline & New Red Fire & $34.0 \mathrm{a}-\mathrm{c}$ & $0.34 \mathrm{a}-\mathrm{c}$ & $14.7 \mathrm{a}-\mathrm{c}$ & $19.1 \mathrm{a}-\mathrm{c}$ \\
\hline \multirow{2}{*}{ WFC100 } & Starfighter & $32.0 \mathrm{a}-\mathrm{e}$ & $0.63 \mathrm{a}$ & $13.2 \mathrm{a}-\mathrm{f}$ & $19.3 \mathrm{a}-\mathrm{c}$ \\
\hline & New Red Fire & $48.0 \mathrm{a}$ & $0.55 \mathrm{ab}$ & $15.0 \mathrm{ab}$ & $20.8 \mathrm{a}-\mathrm{c}$ \\
\hline \multirow{2}{*}{ WF25 } & Starfighter & $9.5 \mathrm{f}$ & $0.19 \mathrm{bc}$ & $9.2 \mathrm{f}-\mathrm{i}$ & $15.9 \mathrm{bc}$ \\
\hline & New Red Fire & $14.3 \mathrm{c}-\mathrm{f}$ & $0.32 \mathrm{a}-\mathrm{c}$ & $12.4 \mathrm{a}-\mathrm{g}$ & $18.2 \mathrm{a}-\mathrm{c}$ \\
\hline \multirow{2}{*}{ WF50 } & Starfighter & $13.7 \mathrm{c}-\mathrm{f}$ & $0.42 \mathrm{a}-\mathrm{c}$ & $9.9 \mathrm{~d}-\mathrm{i}$ & $19.9 \mathrm{a}-\mathrm{c}$ \\
\hline & New Red Fire & $17.5 \mathrm{c}-\mathrm{f}$ & $0.26 \mathrm{a}-\mathrm{c}$ & $14.0 \mathrm{a}-\mathrm{e}$ & $20.4 \mathrm{a}-\mathrm{c}$ \\
\hline \multirow{2}{*}{ WF100 } & Starfighter & $20.3 \mathrm{~b}-\mathrm{f}$ & $0.67 \mathrm{a}$ & $13.3 \mathrm{a}-\mathrm{f}$ & $17.0 \mathrm{a}-\mathrm{c}$ \\
\hline & New Red Fire & $18.0 \mathrm{c}-\mathrm{f}$ & $0.20 \mathrm{bc}$ & $14.4 \mathrm{a}-\mathrm{c}$ & $17.7 \mathrm{a}-\mathrm{c}$ \\
\hline \multirow{2}{*}{ WC25 } & Starfighter & $6.8 \mathrm{f}$ & $0.27 \mathrm{a}-\mathrm{c}$ & $9.4 \mathrm{f}-\mathrm{i}$ & $12.9 \mathrm{bc}$ \\
\hline & New Red Fire & $6.0 \mathrm{f}$ & $0.09 \mathrm{c}$ & $10.8 \mathrm{c}-\mathrm{h}$ & $16.5 \mathrm{a}-\mathrm{c}$ \\
\hline \multirow{2}{*}{ WC50 } & Starfighter & $12.3 \mathrm{c}-\mathrm{f}$ & $0.41 \mathrm{a}-\mathrm{c}$ & $11.9 \mathrm{~b}-\mathrm{g}$ & $16.4 \mathrm{a}-\mathrm{c}$ \\
\hline & New Red Fire & $21.0 \mathrm{~b}-\mathrm{f}$ & $0.35 \mathrm{a}-\mathrm{c}$ & $14.8 \mathrm{a}-\mathrm{c}$ & $20.8 \mathrm{a}-\mathrm{c}$ \\
\hline \multirow{2}{*}{ WC100 } & Starfighter & $23.8 \mathrm{~b}-\mathrm{f}$ & $0.57 \mathrm{ab}$ & $14.3 \mathrm{a}-\mathrm{d}$ & $11.7 \mathrm{c}$ \\
\hline & New Red Fire & $43.3 \mathrm{ab}$ & $0.63 \mathrm{a}$ & $16.4 \mathrm{a}$ & $26.4 \mathrm{a}$ \\
\hline \multirow{2}{*}{ W25 } & Starfighter & $6.7 \mathrm{f}$ & $0.34 \mathrm{a}-\mathrm{c}$ & $9.8 \mathrm{e}-\mathrm{i}$ & $13.0 \mathrm{bc}$ \\
\hline & New Red Fire & $5.5 \mathrm{f}$ & $0.09 \mathrm{c}$ & $11.2 \mathrm{~b}-\mathrm{h}$ & $12.3 \mathrm{c}$ \\
\hline \multirow{2}{*}{ W50 } & Starfighter & $12.3 \mathrm{c}-\mathrm{f}$ & $0.37 \mathrm{a}-\mathrm{c}$ & $10.9 \mathrm{~b}-\mathrm{h}$ & $14.6 \mathrm{bc}$ \\
\hline & New Red Fire & 9.8 ef & $0.19 \mathrm{bc}$ & $12.3 \mathrm{a}-\mathrm{g}$ & $14.2 \mathrm{bc}$ \\
\hline \multirow{2}{*}{ W100 } & Starfighter & $5.8 \mathrm{f}$ & $0.14 \mathrm{c}$ & $8.5 \mathrm{~g}-\mathrm{i}$ & $11.5 \mathrm{c}$ \\
\hline & New Red Fire & $11.3 \mathrm{~d}-\mathrm{f}$ & $0.21 b c$ & $12.1 \mathrm{~b}-\mathrm{g}$ & $17.4 \mathrm{a}-\mathrm{c}$ \\
\hline \multirow{2}{*}{ PM (control) } & Starfighter & $1.5 \mathrm{f}$ & $0.07 \mathrm{c}$ & $6.4 \mathrm{i}^{\circ}$ & $11.0 \mathrm{c}$ \\
\hline & New Red Fire & $3.8 \mathrm{f}$ & $0.08 \mathrm{c}$ & $10.1 \mathrm{e}-\mathrm{i}$ & $10.6 \mathrm{c}$ \\
\hline
\end{tabular}

${ }^{\text {a }}$ Growing medium: WFC25 $=25 \%$ WFC Compost $+75 \%$ Peatmoss (PM); WFC50 = 50\%WFC Compost $+50 \%$ PM; WFC $100=100 \%$ WFC Compost; WF25 $=25 \%$ WF Compost $+75 \%$ PM; WF50 $=50 \%$ WF Compost $+50 \%$ PM; WF $100=100 \%$ WF Compost; WC $25=25 \%$ WC Compost $+25 \%$ PM; WC50 $=50 \%$ WC Compost $+50 \%$ PM; WC100 $=100 \%$ WC Compost $100 \%$; W $25=25 \%$ W Compost $+75 \%$ PM; W50 $=50 \%$ W Compost $+50 \%$ PM; W100 $=100 \%$ W Compost; and PM $=100 \%$ Peatmoss mix by volume. ${ }^{\mathrm{b}}$ Mean values followed by the same letter in a column are not significantly different at $p<0.05$, Tukey's test $(n=4)$.

The growth of lettuce was affected by potting media using composts and corroborated other reports indicating food waste-based compost resulted in greater lettuce growth than commercial peatmoss mix $[2,4,16]$. The optimal proportion of compost incorporated in the growing mix may vary depending on the type of compost as mentioned by Barker and Bryson [5] who demonstrated that in mixes of peatmoss and non-food waste-based compost, optimal lettuce plant growth occurred at compost concentrations of $25 \%$.

The effects of composts as growing media are not limited to plant yield. Nutrients of compost-based growing media have been shown to affect yield and postharvest quality of romaine and iceberg lettuce [20]. High salinity levels of food waste-supplemented composts have been observed in some situations $[4,16]$. Compost maturity may affect EC, oxygen content, and the number of volatile compounds generated from original composting materials in container plant production [21].

To advance utilization of composts on a commercial scale of crop production, further studies will be needed to explore methods to produce standardized composts from waste materials with a constant supply of large amounts of food waste or recyclable materials, from business/marketing systems. Composts of food waste and other recyclable organic materials could be alternatives to commercial potting mix in pot culture production of leafy lettuce. Further studies are necessary to advance the technologies adapted to sustainable agriculture in island based economies. 
Cultivar: Starfighter

Biomass: Shoot

Compost: WFC

$-Y=0.03319 X+0.3613 ; R 2=0.649$ ***

$--Y=(-0.0001355) X^{2}+0.04722 X+0.1919 ; R 2=0.659$ ***

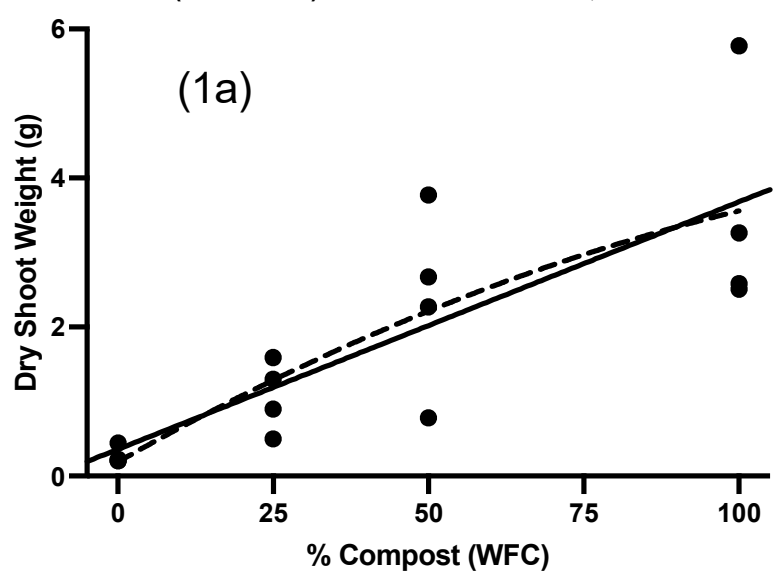

Cultivar: Starfighter

Biomass: Shoot

Compost: WC

$-Y=0.02410 X+0.2781 ; R 2=0.751$ ***

$--Y=(-8.636 e-007) X^{2}+0.02419 X+0.2770 ; R 2=0.751$ ***

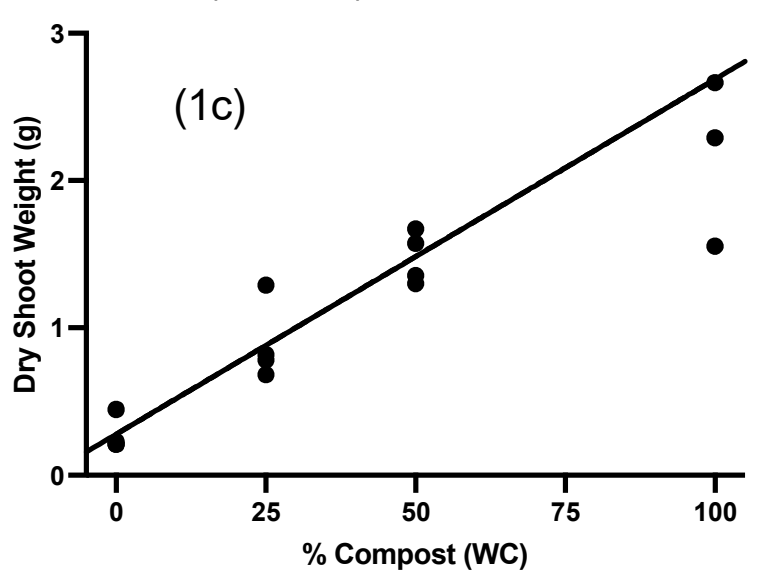

Cultivar: Starfighter

Biomass: Shoot

Compost: WF

$-Y=0.01969 X+0.5291 ; R 2=0.677^{* * *}$

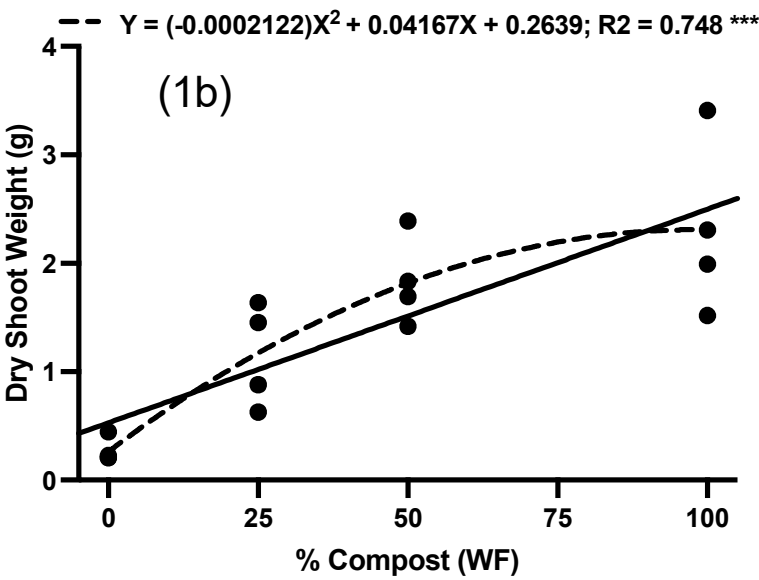

Cultivar: Starfighter

Biomass: Shoot

Compost: W

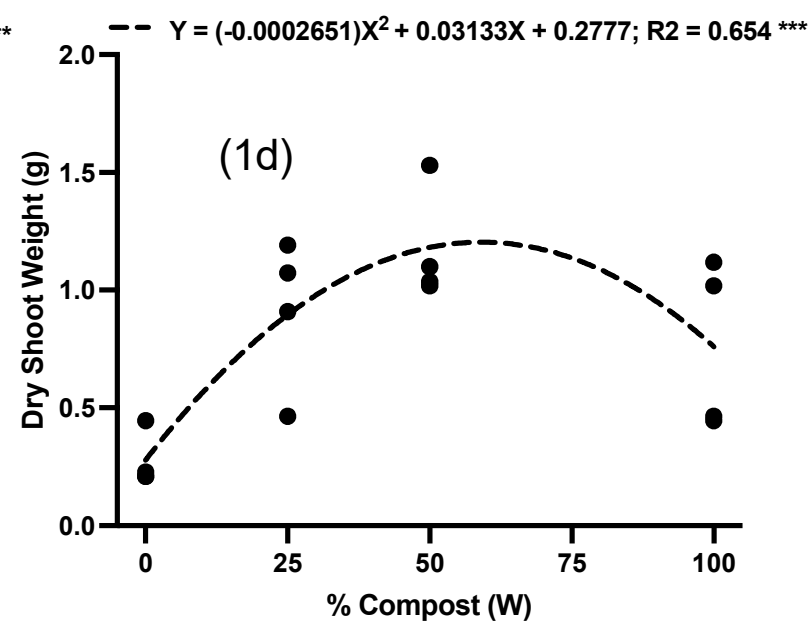

Figure 1. Effect of the percent of compost in growing media on the dry shoot biomass of cv. Starfighter: (1a) Compost WFC; (1b) Compost WF; (1c) Compost WC; and (1d) Compost W. ${ }^{* * *}$ significant at $p<0.001$. 


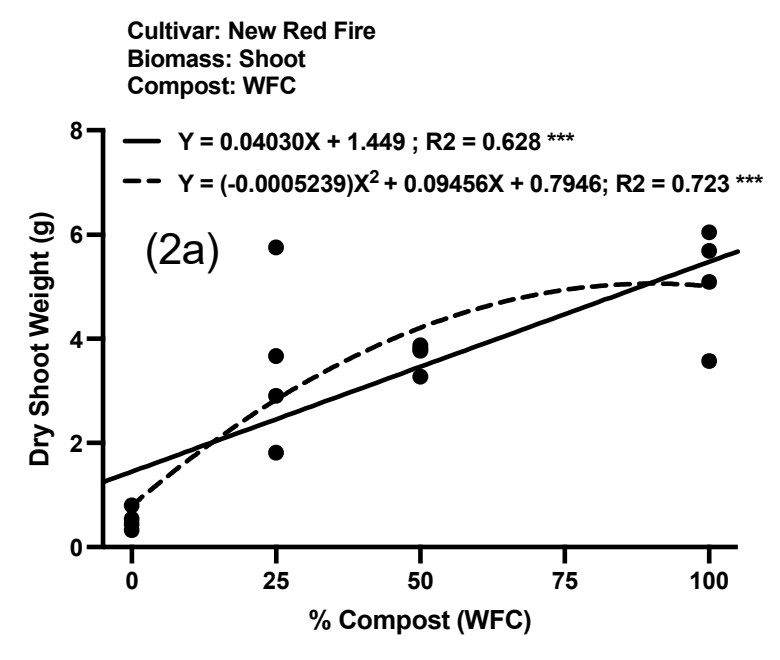

Cultivar: New Red Fire

Biomass: Shoot

Compost: WC

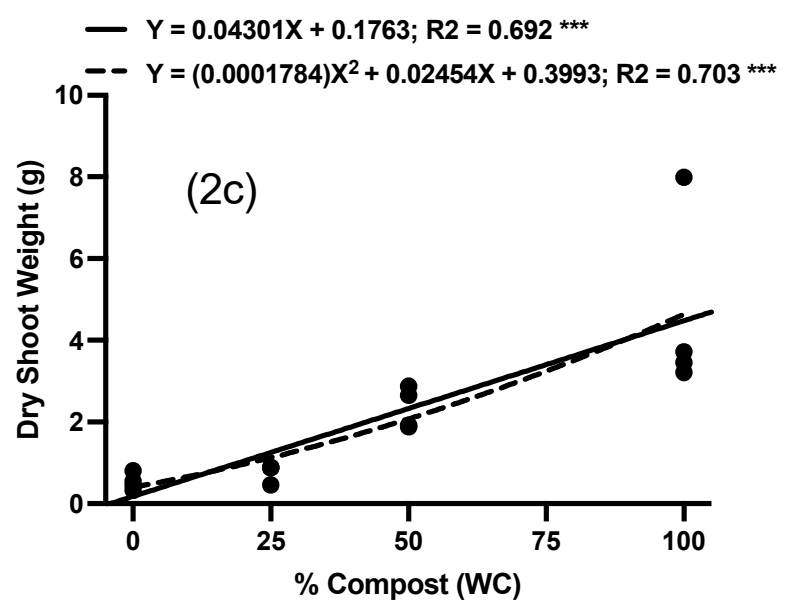

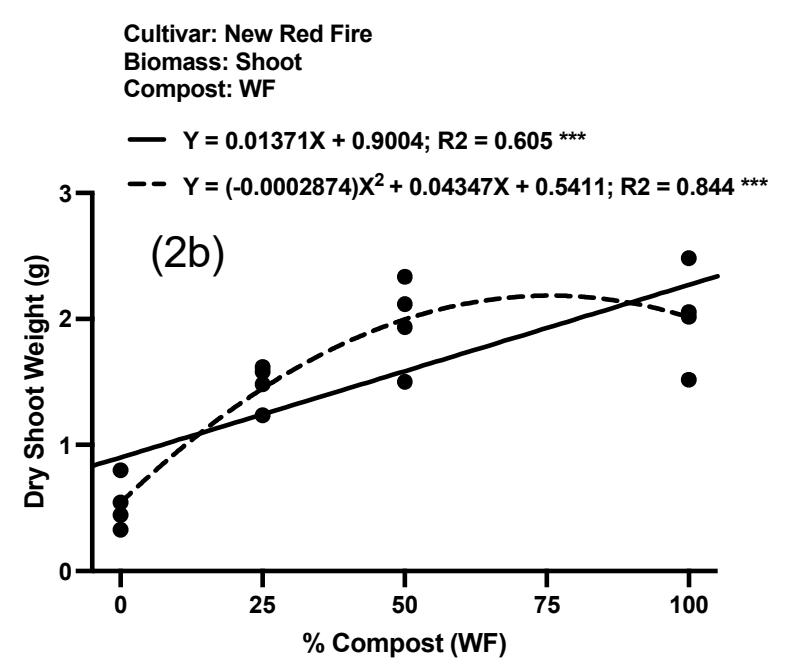

Cultivar: New Red Fire

Biomass:Shoot

Compost: W

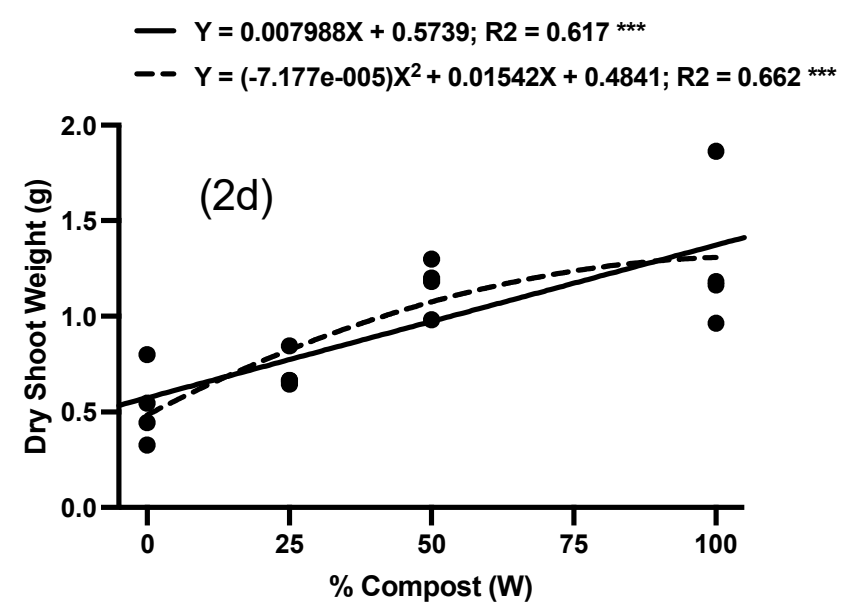

Figure 2. Effect of the percent of compost in growing media on the dry shoot biomass of cv. New Red Fire: (2a) Compost WFC; (2b) Compost WF; (2c) Compost WC; and (2d) Compost. ${ }^{* * *}$ significant at $p<0.001$. 
Cultivar: Starfighter

Biomass: Root

Compost: WFC

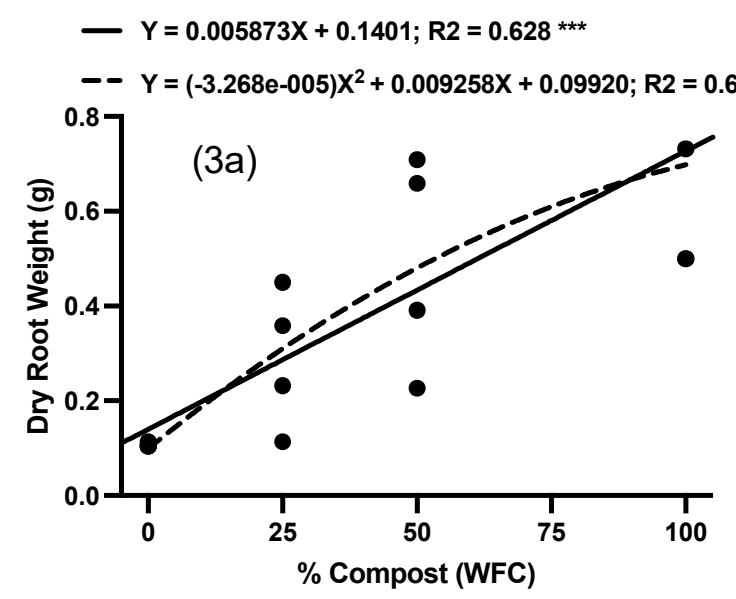

Cultivar: Starfighter

Biomass: Root

Compost: WC

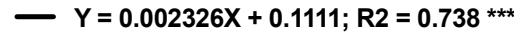

$--Y=(-9.173 e-006) X^{2}+0.003276 X+0.09963 ; R 2=0.739 * * *$

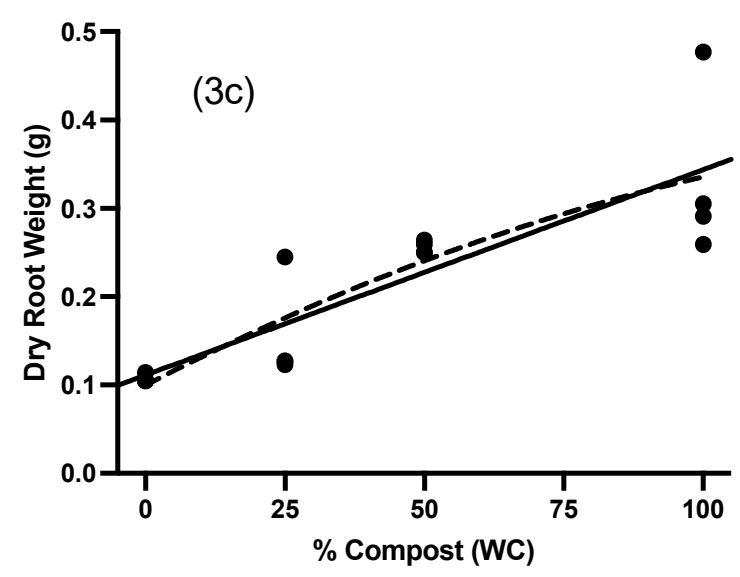

Cultivar: Starfighter

Biomass: Root

Compost: WF

$-\mathrm{Y}=0.003871 \mathrm{X}+0.1590 ; \mathrm{R} 2=0.663$ ***

$--Y=(-2.875 e-005) X^{2}+0.006849 X+0.1231 ; R 2=0.696$ ***

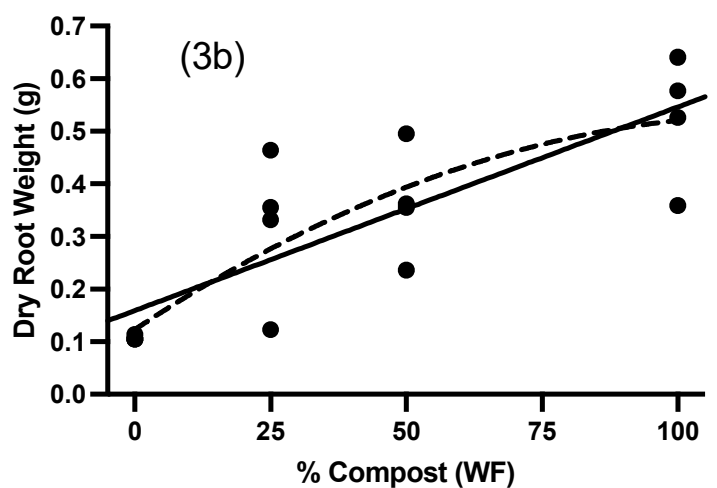

Cultivar: Starfighter

Biomass: Root

Compost: W

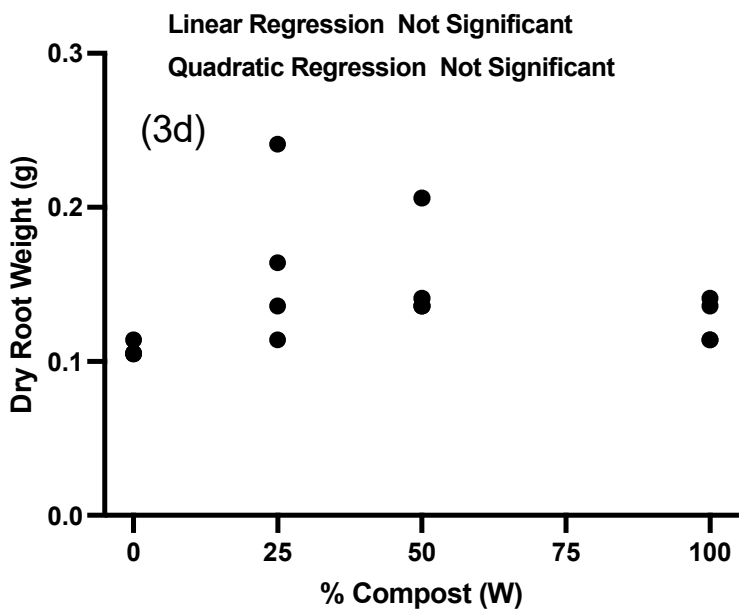

Figure 3. Effect of the percent of compost in growing media on the dry root biomass of cv. Starfighter: (3a) Compost WFC; (3b) Compost WF; (3c) Compost WC; and (3d) Compost. ** and ${ }^{* * *}$ significant at $p<0.01$ and $p<0.001$, respectively. 
Cultivar: New Red Fire

Biomass: Root

Compost: WF

$Y=0.001127 X+0.1880 ; R 2=0.254$

$-\quad Y=(-5.138 e-005) X^{2}+0.006449 X+0.1237 ; R 2=0.728$ ***

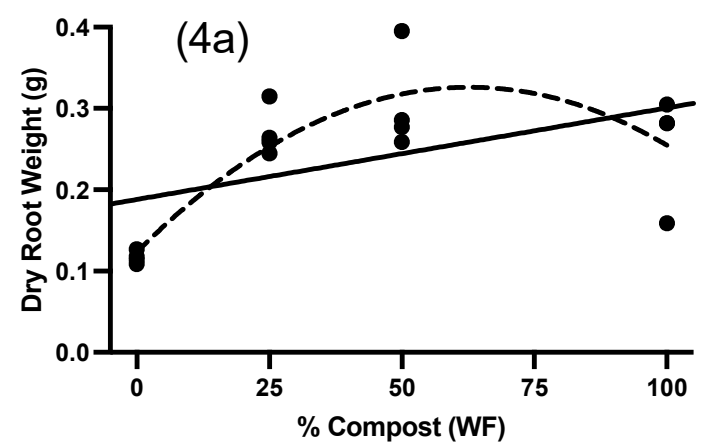

Cultivar: New Red Fire

Biomass: Root

Compost: WC

$-Y=0.005328 X+0.05095 ; R 2=0.650 * * *$

$-Y=(4.562 e-005) X^{2}+0.0006035 X+0.1080 ; R 2=0.692$ ***

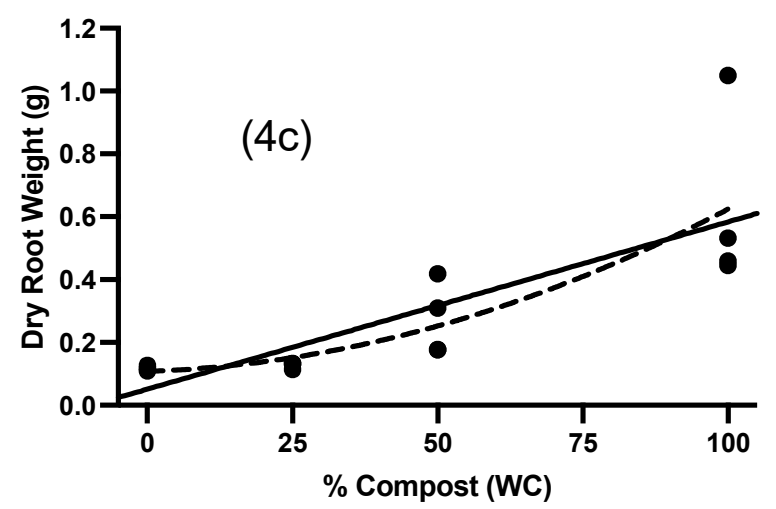

Cultivar: New Red Fire

Biomass: Root

Compost: WFC

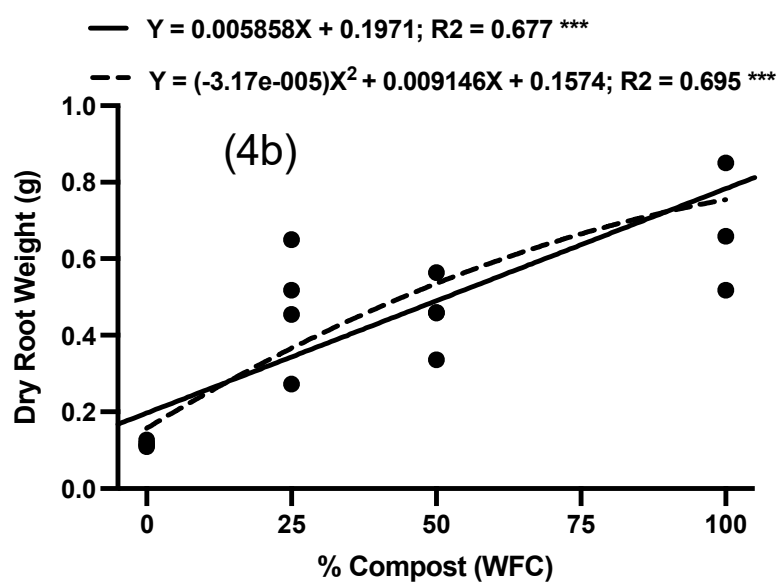

Cultivar: New Red Fire

Biomass: Root

Compost: W

$-Y=0.0006069 X+0.11395 ; R 2=0.363$ *

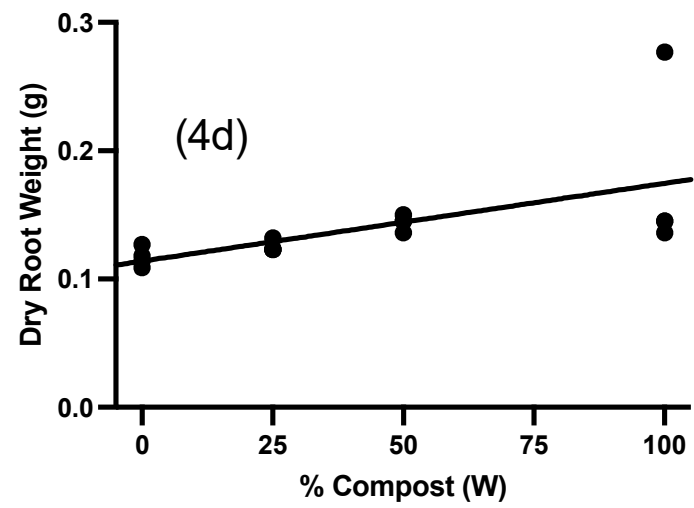

Figure 4. Effect of the percent of compost in growing media on the dry root biomass of cv. New Red Fire: (4a) Compost WFC; (4b) Compost WF; (4c) Compost WC; and (4d). * and ${ }^{* * *}$ significant at $p<0.05$ and $p<0.001$, respectively.

Author Contributions: Conceptualization, M.M.; methodology, M.M., S.C.; software, M.M., S.C.; validation, M.M., S.C.; formal analysis, M.M., S.C.; investigation, S.C.; resources, M.M.; data curation, S.C..; writing-original draft preparation, S.C.; writing-review and editing, M.M.; visualization, S.C.; supervision, M.M.; project administration, M.M., S.C.; funding acquisition, M.M. All authors have read and agreed to the published version of the manuscript.

Funding: The research was supported by the Department of Interior Grant No. TAP-Guam-UOG2014-1, USDA/HATCH under Grant 217050, and USDA/NIFA/RIIA Grant 2016-70004-25720.

Institutional Review Board Statement: Not applicable.

Informed Consent Statement: Not applicable.

Data Availability Statement: The data presented in this study are available on request from the corresponding author. 
Acknowledgments: The authors thank Ferdinand Galsim, Edwin Paulino, and Mohammed Golabi for technical assistance in making compost and Daryl Keller, Gerard Chargualaf, and Joseph Tuquero for technical assistance to test growing media in the plant nursery. The authors thank Chieriel Desamito, Adrian Ares, and Mohammed Golabi for reviewing the manuscript.

Conflicts of Interest: The authors declare no conflict of interest. The funders had no role in the design of the study; in the collection, analyses, or interpretation of data; in the writing of the manuscript, or in the decision to publish the results.

\section{References}

1. Silvan, M.; Jokinen, K.; Näkkliä, J.; Tahvonen, R. Swift recovery of Sphagnum carpet and carbon sequestration after shallow Sphagnum biomass harvesting. Mires Peat 2017, 20,1-11.

2. Raviv, M.R.; Zaidman, B.; Kapulnik, Y. The use of compost as a peat substitute for organic vegetable transplants production. Compos. Sci. Util. 1998, 6, 46-52. [CrossRef]

3. Lee, J.J.; Park, R.D.; Kim, Y.W.; Shim, J.H.; Chae, D.H.; Rim, Y.S.; Sohn, B.K.; Kim, T.H.; Kim, K.Y. Effect of food waster compost on microbial population, soil enzyme activity and lettuce growth. Bioresour. Technol. 2004, 93, 21-28. [CrossRef] [PubMed]

4. Clark, S.; Cavigelli, M. Suitability of composts as potting media for production of organic vegetable transplants. Compos. Sci. Util. 2005, 13, 150-156. [CrossRef]

5. Barker, A.V.; Bryson, G.M. Comparisons of composts with low or high nutrient status for growth of plants in containers. Commun. Soil Sci. Plant Anal. 2006, 37, 1303-1319. [CrossRef]

6. Díaz-Pérez, J.C.; Camacho-Ferre, F. Effects of composts in substrates on the growth of tomato transplants. Horttechnology 2010, 20, 361-367. [CrossRef]

7. Yang, L.; Li, F.; Chu, H. Effects of food waste compost on soil microbial populations, tomato yield, and tomato quality. Commun Soil Sci. Plant Anal. 2014, 45, 1049-1058. [CrossRef]

8. Santos, F.T.; Goufo, P.; Santos, C.; Botelho, D.; Fonsecxa, J.; Queiros, A.; Costa, M.; Trindada, H. Comparison of five agro-industrial waste-based composts as growing media for lettuce: Effect on yield, phenolic compounds and vitamin C. Food Chem. 2016, 209, 293-301. [CrossRef] [PubMed]

9. Gelman, F.; Binstock, R.; Halicz, L. Application of the Walkley-Black titration for the organic carbon quantification in organic rich sedimentary rocks. Fuel 2012, 96, 608-610. [CrossRef]

10. Olsen, S.R.; Cole, C.V.; Watanabe, F.S.; Dean, L.A. Estimation of Available Phosphorus in Soils by Extraction with Sodium Bicarbonate; Circular, No. 939; US Department of Agriculture: Washington, DC, USA, 1954.

11. Baker, D.E.; Shur, N.H. Atomic absorption and flame emission spectrometry. In Methods of soil analysis: Part 2 Chemical and Microbiological Properties, 2nd ed.; Number 9 Part 2 of the Series; Page, A.L., Ed.; Agronomy, American Society of Agronomy, Inc.: Madison, WI, USA; Soil Science Society of America, Inc.: Madison, WI, USA, 1983; pp. 13-27.

12. Matejovic, I. Determination of carbon, hydrogen, and nitrogen in soils by automated elemental analysis (dry combustion method). Commun. Soil Sci. Plant Anal. 1993, 24, 2213-2222. [CrossRef]

13. R Core Team. R: A Language and Environment for Statistical Computing; R Core Team: Vienna, Austria, 2017; Available online: https:/ / www.R-project.org/ (accessed on 17 July 2019).

14. Bates, D.; Maechler, M.; Bolker, B.; Walker, S. Fitting linear mixed-effects models using lme4. J. Stat. Softw. 2015, 67, 1-48. [CrossRef]

15. Kumar, M.; Ou, Y.L.; Lin, J.G. Co-composting of green waste and food waste at low C/N ratio. J. Waste Manag. 2010, 30, 602-609. [CrossRef] [PubMed]

16. Lee, I.B.; Kim, P.J.; Chang, K.W. Evaluation of stability of compost prepared with Korean food wastes. J. Soil Sci. Plant Nutr. 2002, 48, 1-8. [CrossRef]

17. Grant Lipp, A.E.; Goodall, D.W. Nutrient interactions and deficiency diagnosis in the lettuce. Aust. J. Biol. Sci. 1958, 11, 471-484. [CrossRef]

18. Goodall, D.W.; Grant, A.E.; Slater, W.G. Nutrient interactions and deficiency diagnosis in the lettuce. Aust. J. Biol. Sci. 1955, 8 , 301-329. [CrossRef]

19. Bartholomew, R.P.; Janssen, G. Luxury consumption of potassium by plants and its significance. Agron. J. 1929, 21, 751-765. [CrossRef]

20. Hoque, M.M.; Ajwa, H.; Othman, M.; Smith, R.; Cahn, M. Yield and postharvest quality of lettuce in response to nitrogen, phosphorus, and potassium fertilizers. HortScience 2010, 45, 1539-1544. [CrossRef]

21. Brinton, W.F.; Evans, E. How compost maturity affects container grown plants. Biocycle 2001, 42, 56-59. 